УДК 615.1:615.22:614.27

DOI https://doi.org/10.11603/2312-0967.2021.2.12183

\title{
АНАЛІЗ ЕКОНОМІЧНОЇ ДОСТУПНОСТІ ОКРЕМИХ ГРУП КАРДІОЛОГІЧНИХ ПРЕПАРАТІВ В УКРАЇНІ ЗА 2016-2020 РОКИ
}

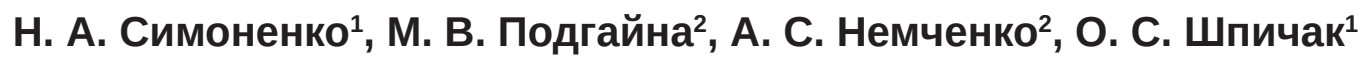 \\ Інститут підвищення кваліфрікації спеціалістів фрармації Національного \\ формацевтичного університету, Харків ${ }^{1}$ \\ Національний фрармацевтичний університет, Харків \\ shpychak.oleg@gmail.com
}

\section{ІНФОРМАЦІЯ}

Надійшла до редакції / Received 28.04.2021

Після доопрацювання / Revised: 02.06.2021

Прийнято до друку / Accepted: 05.06.2021

\section{Ключові слова:}

серцево-судинні захворювання; кардіологічні препарати; адекватність платоспроможності; економічна доступність.

\begin{abstract}
АНОТАЦІЯ
Мета роботи. Аналіз економічної доступності лікарських засобів (ЛЗ) срармакотерапевтичної групи II рівня анатомічно-терапевтично хімічної класифрікації - «Кардіологічні препарати» на вітчизняному фрармацевтичному ринку у 2016-2020 роках.

Матеріали і методи. Дані щодо пропозицій дистриб'юторів були отримані на платорормі «Моріон» за 2016-2020 роки, усереднено пропозиції дистриб'юторів за групою «Кардіологічні препарати», код АТХ С01. Здійснено аналіз роздрібних цін за ЛЗ групи С01 - Кардіологічні препарати та окремо за групою С01E X Різні комбіновані кардіологічні препарати. За результатами розрахунків ланцюгового індексу цін $\left(\mathrm{I}_{\mathrm{p}}\right)$, показників адекватності платоспроможності $\left(\mathrm{C}_{\mathrm{as}}\right)$ та економічної доступності (D) встановлено загальні тенденції до зростання роздрібних цін кардіологічних препаратів в Україні впродовж останніх 5-ти років та необхідність до імпортозаміщення лз за групою, що досліджується.

Результати й обговорення. Найвищим значенням індексу роздрібних цін впродовж 2016-2020 років характеризувалася група C01 A - Серцеві глікозиди, найменший показник росту цін відповідав групі С01 В Антиаритмічні засоби. Встановлено, що для всіх фрармакотерапевтичних підгруп групи C01 було характерне щорічне зниження показника адекватності платоспроможності. Одночасно визначено динаміку підвищення економічної доступності в середньому на 5 \% - 3 2,46 в 2016 р. до 2,33 в 2020 р. Встановлено, що для групи C01E X «Різні комбіновані кардіологічні препарати» зберігаються тенденції, характерні для усієї групи С01 «Кардіологічні препарати».

Висновки. Визначено загальну тенденцію до помірного росту цін, разом з тим розраховані показники доступності дали можливість визначити динаміку до поступового зростання економічної доступності кардіологічних препаратів, у тому числі групи C01E X - Різні комбіновані кардіологічні препарати.
\end{abstract}

Вступ. Надання доступної, безпечної та якісної допомоги пацієнтам, що хворіють на соціально-важливі патології, стає дедалі значущішим через недостатність бюджетних коштів [1]. Відповідно до рекоменда- цій ВООЗ, доступність лікарських засобів є важливим фактором, що визначає доступність системи охорони здоров'я для пацієнта в цілому. Про важливість проблеми забезпечення доступності ЛЗ у світі свідчить

ISSN 2312-0967. Pharmaceutical review. 2021. № 2 
те, що у травні 2019 року на 72-й Всесвітній асамблеї охорони здоров'я (72 ${ }^{\text {nd }}$ World Health Assembly - WHA72) окрема увага приділялася тематиці доступності ліків [2]. Особливо питання економічної доступності ЛЗ стосується соціально-значущих захворювань, до яких в Україні віднесено групу серцево-судинних захворювань (СС3). Так, за даними ВОО3, СС3 - це основна причина смертності у всьому світі. Ця проблема в різному ступені зачіпає країни з низьким і середнім рівнем доходу. Більше 80 \% випадків смертей від СС3 стається майже однаково серед чоловіків і жінок [2]. Про актуальність фрармацевтичного забезпечення хворих на ССЗ свідчить розробка та активне фрункціонування в Україні з 01.04.2017 р. Державної програми «Доступні ліки» (далі - Програма), у межах якої за 24,5 млн електронними рецептами хворими отримано ЛЗ для лікування ССЗ, бронхіальної астми та цукрового діабету, безкоштовно або з доплатою. До Програми наразі включено 18 найменувань ЛЗ для лікування СС3 за міжнародними непатентованими назвами, які представлені сімома фрармакотерапевтичними групами II рівня ATX (анатомічно-терапевтична хімічна, АТX) класиорікації: C01 кардіологічні препарати (4 МНH), С03 сечогінні препарати (3 MHН), C07 блокатори бета-адренорецепторів (4 MHН), С08 антагоністи кальцію (3 МНH), C09 засоби, що діють на ренін-ангіотензинову систему (2 MHН), С10 гіполіпідемічні засоби (1 MHН), В01 антитромботичні засоби (1 MHН) [3-5]. До групи С01 Кардіологічні препарати у Програмі були включені $4 \mathrm{MHH}$, а саме: дигоксин, аміодарон, нітрогліцерин та ізосорбіду динітрат, що склало 23,5 \% від усіх Л3 для лікування ССЗ, включених до Програми [3]. Враховуючи високі показники поширеності та смертності від CC3, а також особливу увагу держави на забезпечення доступності ЛЗ для лікування СС3, метою проведеного дослідження став аналіз економічної доступності фрармакотерапевтичної групи II рівня анатомотерапевтичної хімічної класифрікації - «Кардіологічні препарати» на вітчизняному фрармацевтичному ринку у 2016-2020 роках.

Важливим етапом у вивченні Л3 для терапії СС3, враховуючи поширеність та розповсюдженість вказаних патологій, $є$ аналіз цін та основних показників, що визначають економічну доступність Лз [6].

Матеріали і методи. Для визначення фрактичного рівня економічної доступності срармакотерапевтичної групи «Кардіологічні препарати» використано результати аналізу оптового фрармацевтичного ринку, зокрема пропозицій дистриб'юторів [7]. Дані щодо роздрібних цін на ЛЗ за групою «Кардіологічні препарати», код АТX C01, за 2016-2020 роки отримано на платформі «Моріон». На виконання мети дослідження було здійснено аналіз роздрібних цін за усіма Л3 групи С01 - Кардіологічні препарати та окремо за групою C01E X - Різні комбіновані кардіологічні препарати, а також розрахунок й узагальнення ланцюгового індексу цін $\left(\mathrm{I}_{\mathrm{p}}\right)$, показників адекватності платоспроможності ( $\left.\mathrm{C}_{\mathrm{as}}\right)$ та економічної доступності (D) Л3 за 2016-2020 роки. Для визначення даних показників було використано формулу, розроблену науковцями кафедри організації та економіки фрармації НФаУ під керівництвом профресора Немченко А. С. та апробовану на багатьох наукових дослідженнях (табл. 1).

\section{Таблиця 1}

Маркетингові показники, що характеризують доступність лікарських засобів

\begin{tabular}{|c|c|}
\hline $\begin{array}{l}\text { Ланцюговий індекс } \\
\text { (Ig) середньо- } \\
\text { статистичних } \\
\text { роздрібних цін }\end{array}$ & $\begin{array}{l}I_{g}=\frac{1}{n} \sum_{i=1}^{n} I_{i}, I_{p}=\frac{\overline{P_{i}}}{P_{i o}}, \\
\frac{\text { де } I_{p}-\text { ланцюговий індекс цін; }}{\bar{P}_{i}}-\text { середня арифрметична зважена роздрібна ціна і-го препарату у поточному періоді; } \\
P_{\text {io }}-\text { середня арифрметична зважена роздрібна ціна і-го препарату у попередньому періоді; } \\
n-\text { кількість препаратів у групі, що досліджується }\end{array}$ \\
\hline $\begin{array}{l}\text { Коефріцієнт } \\
\text { адекватності } \\
\text { платоспроможності } \\
\left(C_{\text {a.s. }}\right)\end{array}$ & $\begin{array}{l}C_{\text {a.s. }}=\frac{\bar{P}}{W_{\text {a.w. }}} \times 100 \% \\
\frac{\text { де } C_{\text {a.s. }}-\text { коесріцієнт адекватності платоспроможності; }}{P}-\text { середня роздрібна ціна препарату за певний період часу; } \\
W_{\text {a.w. }}-\text { середня заробітна плата за відповідний період часу }\end{array}$ \\
\hline Доступність ЛЗ (D) & $\begin{array}{l}D=\frac{I_{x} \times Z_{\min }}{I_{s} \times V_{k}} \\
\text { де } I_{x}-\text { індекс зміни середньої заробітної плати за визначений період; } \\
I_{s}-\text { зведений індекс цін на ЛЗ за той же період; } \\
Z_{\text {min }}-\text { мінімальна заробітна плата у країні; } \\
V_{k}-\text { величина прожиткового мінімуму за період, що досліджувався }\end{array}$ \\
\hline
\end{tabular}

ISSN 2312-0967. Фармацевтичний часопис. 2021. № 2 
Коефіцієнт адекватності платоспроможності показує відношення ціни препарату до середнього розміру доходу працездатного громадянина (середня заробітна плата).

Чим нижчий показник адекватності платоспроможності, тим доступніший ЛЗ для населення. Показник доступності - відносний показник, який включає відносні величини вартості препарату та доходів, зокрема індекси ціни Лз та зміни заробітної плати. Відповідно до даних літературних джерел встановлено, що для гарантованої державою медичної та фрармацевтичної допомоги показник доступності повинен дорівнювати одиниці або бути більшим за одиницю. Чим вище значення показника доступності ЛП, тим економічно прийнятнішою є терапія таким ЛЗ.

Під час дослідження для розрахунку адекватності платоспроможності та доступності ЛЗ використано дані, які встановлені Державною службою статистики України за відповідний період (табл. 2).

Дослідження здійснювали з використанням сучасних методів аналізу, систематизації та узагальнення, математико-статистичних розрахунків.

Результати й обговорення. За даними Державного експертного центру МОЗ в Україні зареєстровано 44 МНH, або 257 Л3 фрармакотерапевтичної групи «Кардіологічні препарати» $з$ урахуванням лікарських фрорм (ЛФ). Структурний аналіз доступності кардіологічних препаратів на фрармацевтичному ринку підтвердив широту асортименту даної групи [7].

Аналіз асортименту ЛЗ групи «Кардіологічні препарати» за МНH показав, що частка ЛЗ, які увійшли до Державної програми «Доступні ліки» від загальної кількості ЛЗ групи, представлених на вітчизняному ринку у 2020 році, склала 9 \% (4 МНН з 44). Загальна кількість торгівельних назв ЛЗ групи «Кардіологічні препарати» із урахуванням ЛФ, що увійшли до Програми, склала 45 Л3, або 18 \% від представлених на вітчизняному ринку Л3 групи (45 з 257 Л3). Зокрема, за МНН «аміодарон» - 14 ЛЗ з урахуванням ЛФ, «дигоскин» - 5 Л3, «ізосорбіду динітрат» - 18 Л3, «нітрогліцерин» - 8 Л3. Одночасно у 2019 р. у звіті ВООЗ «Оцінка програми доступних лікарських засобів в Україні» було проаналізовано роботу Державної про- грами «Доступні ліки» за 2017-2018 рр. та вказано, що за групою С01 «Кардіологічні препарати» середня річна сума доплат на одного пацієнта до запровадження Державної програми складала - 434 грн, а після запровадження - 18 грн, тобто, фактично, економічна доступність лз групи, що входять до Державної програми, збільшилася у 24 рази, що, безсумнівно, є позитивним явищем [8].

Разом з тим, частка Л3, що увійшли до Програми, у фрармакотерапевтичній групі «Кардіологічні препарати» менша 20 \% (а за МHН - менша $10 \%$ ), тому доцільним $€$ аналіз економічної доступності усіх препаратів групи із використанням фрактичних роздрібних цін у ретроспективі останніх п'яти років.

Результати розрахунків ланцюгового середньорічного індексу роздрібних цін за загальною сукупністю та у структурі груп кардіологічних препаратів показали поступове підвищення цін на препарати даної групи, зокрема середньорічний темп росту роздрібних цін за групою С01 склав 9 \%. Найвищим значенням індексу роздрібних цін серед фрармакотерапевтичних підгруп характеризувалася одна з найменш численних груп - C01 A - Серцеві глікозиди, одночасно найменший показник росту цін впродовж 2016-2020 років відповідав групі С01 В - Антиаритмічні засоби. У першому досліджуваному періоді - у 2017 році відносно 2016 року - спостерігалося навіть середньорічне зниження цін на препарати даної групи на 5 \% (табл. 3).

Розрахунки показника адекватності платоспроможності дали можливість визначити, що для всіх орармакотерапевтичних підгруп було характерне щорічне зниження показника адекватності платоспроможності ЛП, що свідчило про підвищення економічної доступності препаратів групи. Справедливо зазначити, що найнижчим показником у загальній структурі характеризувалася підгрупа C01 A - Cерцеві глікозиди, для якої було визначено найбільший приріст роздрібних цін.

Додаткового пояснення потребує високе значення

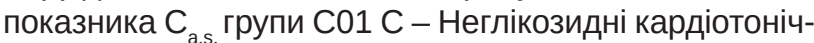
ні засоби. Низька економічна доступність препаратів групи C01 C - Неглікозидні кардіотонічні засоби - се-

Таблиця 2

Основні соціально-економічні показники в Україні за 2016-2020 роки

\begin{tabular}{|l|c|c|c|c|c|}
\hline \multicolumn{1}{|c|}{ Рік/ } \\
\multicolumn{1}{|c|}{ показник } & 2016 & 2017 & 2018 & 2019 & 2020 \\
\hline $\begin{array}{l}\text { Середня заробітна плата за відповідний } \\
\text { період, грн }\end{array}$ & 6475 & 8777 & 10573 & 12264 & 14179 \\
\hline $\begin{array}{l}\text { Індекс зміни середньої заробітної плати } \\
\text { за визначений період }\end{array}$ & & 1,36 & 1,20 & 1,16 & 1,16 \\
\hline Мінімальна заробітна плата у країні, грн & 1476 & 3200 & 3723 & 4173 & 4723 \\
\hline $\begin{array}{l}\text { Середня величина прожиткового мінімуму } \\
\text { за період, що досліджувався, грн }\end{array}$ & 1544 & 1700 & 1853 & 2027 & 2189 \\
\hline
\end{tabular}

ISSN 2312-0967. Pharmaceutical review. 2021. № 2 
Фармакоекономіка

Pharmacoeconomics

Таблиця 3

Структурний аналіз показників економічної доступності кардіологічних препаратів за 2016-2020 роки в Україні

\begin{tabular}{|c|c|c|c|c|c|}
\hline Рік/група лЗ & 2016 & 2017 & 2018 & 2019 & 2020 \\
\hline & \multicolumn{5}{|c|}{ Ланцюговий індекс цін, Ір } \\
\hline За групою С01 & - & 1,05 & 1,12 & 1,08 & 1,09 \\
\hline$\square$ C01 A - Серцеві глікозиди & - & 1,1 & 1,13 & 1,1 & 1,14 \\
\hline$\square$ С01 В - Антиаритмічні засоби & - & 0,95 & 1,03 & 1,1 & 1,04 \\
\hline$\square$ C01 C - Неглікозидні кардіотонічні засоби & - & 1,1 & 1,21 & 1,02 & 1,04 \\
\hline ૧ C01 D - Вазодилататори, що застосовуються у кардіології & - & 1,03 & 1,1 & 1,05 & 1,11 \\
\hline \multirow[t]{2}{*}{ C01 E - Інші кардіологічні препарати } & - & 1,08 & 1,13 & 1,11 & 1,11 \\
\hline & \multicolumn{5}{|c|}{ Коесріцієнт адекватності платоспроможності, $\mathrm{C}_{\text {a.s. }}$} \\
\hline За групою С01 & 9,33 & 5,71 & 5,07 & 4,69 & 4,55 \\
\hline$\square$ C01 A - Серцеві глікозиди & 0,22 & 0,16 & 0,17 & 0,15 & 0,16 \\
\hline$\square$ С01 В - Антиаритмічні засоби & 3,39 & 2,7 & 2,3 & 2,01 & 1,88 \\
\hline$\square$ С01 C - Неглікозидні кардіотонічні засоби & 37,79 & 21,6 & 19,44 & 18,18 & 17,77 \\
\hline$\square$ C01 D - Вазодилататори, що застосовуються у кардіології & 1,42 & 1,04 & 0,8 & 0,81 & 0,77 \\
\hline \multirow[t]{2}{*}{ C01 E - Інші кардіологічні препарати } & 3,84 & 3,04 & 2,65 & 2,32 & 2,16 \\
\hline & \multicolumn{5}{|c|}{ Коефріцієнт доступності, D } \\
\hline За групою С01 & - & 2,46 & 2,25 & 2,71 & 2,33 \\
\hline$\square$ C01 A - Серцеві глікозиди & - & 2,31 & 2,14 & 2,19 & 2,22 \\
\hline$\square$ С01 В - Антиаритмічні засоби & - & 2,8 & 2,37 & 2,23 & 2,42 \\
\hline$\square$ С01 C - Неглікозидні кардіотонічні засоби & - & 2,34 & 2,08 & 4,67 & 2,42 \\
\hline — C01 D - Вазодилататори, що застосовуються у кардіології & - & 2,46 & 2,44 & 2,29 & 2,32 \\
\hline C01 E - Інші кардіологічні препарати & - & 2,4 & 2,21 & 2,19 & 2,29 \\
\hline
\end{tabular}

реднє значення показника адекватності платоспроможності за 2016-2020 роки - 22,96, порівняно із середніми показниками за іншими підгрупами - від 0,17 до 2,8 - зумовлене наявністю у групі високовартісного препарату - Симдакс, Оріон (Фінляндія), конц. д/п інфр. р-ну 2,5 мг/мл фрл. 5 мл, №1 (діюча речовина левосимендан), роздрібна ціна якого складала від 20924,55 у 2016 р. до 22 089,68 грн у 2020 р., відпо-

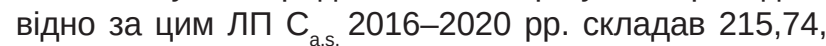
що й вплинуло на середній показник у групі в цілому.

Отримані результати підтвердили необхідність застосування показника доступності, D, що цілеспрямовано характеризує економічну доступність кардіологічних препаратів для населення (табл. 3). Аналіз середнього показника доступності кардіологічних препаратів показав незначне зниження, зокрема 3 2,46 у 2016 р. до 2,33 у 2020 р., відповідно, що склало більше $5 \%$.

За роки дослідження найвищим показником доступності характеризувалися кардіологічні препарати у 2019 році (D-2,71). Однак у 2020 році було встановлено зниження даного показника на 14 \%. Разом 3 тим, потрібно вказати на те, що впродовж 20162020 років для групи С01 - Кардіологічні препарати та підгруп C01A-E значення показника доступності було більшим за одиницю, що вважається прийнят- ним для споживачів та фрактично визначає економічну доступність кардіологічних препаратів, зареєстрованих на вітчизняному фрармацевтичному ринку, для населення України в цілому.

Враховуючи використання групи C01E X - Різні комбіновані кардіологічні препарати, як групу порівняння при вивченні фрармакологічної активності ЛЗ, ми провели аналіз цінових характеристик препаратів даної групи в ретроспективі останніх 5-ти років. Узагальнені результати розрахунків ланцюгового індексу цін, показників адекватності платоспроможності та доступності наведено у таблиці 4.

Як свідчать дані таблиці, у групі 4-го рівня АTXкласифрікації C01E X «Різні комбіновані кардіологічні препарати», зберігаються описані вище тенденції, характерні для усієї групи С01 «Кардіологічні препарати», що підтверджує правильність здійснених розрахунків.

Отже, здійснений аналіз роздрібних цін кардіологічних препаратів на вітчизняному оптовому ринку засвідчив загальну тенденцію до помірного росту цін, разом із тим, розраховані показники доступності дали можливість визначити динаміку до поступового зростання економічної доступності кардіологічних препаратів, у тому числі групи C01E X - Різні комбіновані кардіологічні препарати.

ISSN 2312-0967. Фармацевтичний часопис. 2021. № 2 
Таблиця 4

Узагальнений аналіз показників економічної доступності групи «Різні комбіновані кардіологічні препарати» за 2016-2020 роки в Україні

\begin{tabular}{|c|c|c|c|c|c|}
\hline Рік/показник & 2016 & 2017 & 2018 & 2019 & 2020 \\
\hline \multirow{2}{*}{ Ланцюговий індекс цін, Ір } & & & & & \\
\hline & - & 1,08 & 1,12 & 1,15 & 1,11 \\
\hline \multirow{2}{*}{ Коефріцієнт адекватності платоспроможності, C } & & & & & \\
\hline & 1,88 & 1,35 & 1,20 & 0,84 & 0,76 \\
\hline \multirow{2}{*}{ Коесріцієнт доступності, D } & & & & & \\
\hline & - & 2,40 & 2,18 & 2,14 & 2,29 \\
\hline
\end{tabular}

Висновки. 1. Показано, що середня річна сума доплат на одного пацієнта до запровадження урядової програми «Доступні ліки» складала - 434 грн, а після запровадження - 18 грн, тобто фрактично, економічна доступність ЛЗ групи, що входять до Державної програми збільшилася у 24 рази, що свідчить про покращення доступності основних кардіологічних ліків, які реімбурсуються для хворих.

2. Аналіз ланцюгового середньорічного індексу роздрібних цін у структурі груп кардіологічних препаратів показав поступове підвищення цін на препарати даної групи, зокрема середньорічний темп росту роздрібних цін за групою С01 склав $9 \%$.

3. Найвищим значенням індексу роздрібних цін впродовж 2016-2020 років характеризувалася група - C01 A - Серцеві глікозиди, найменший показник росту цін відповідав групі С01 В - Антиаритмічні засоби.

4. Встановлено, що для всіх фрармакотерапевтичних підгруп групи C01 було характерне щорічне зниження показника адекватності платоспроможності.

5. Низька економічна доступність препаратів групи
C01 C - Неглікозидні кардіотонічні засоби - середнє значення показника адекватності платоспроможності за 2016-2020 роки - 22,96, порівняно із середніми показниками за іншими підгрупами - від 0,17 до 2,8 - було зумовлене наявністю у групі високовартісного препарату - Симдакс, Оріон (Фінляндія). А також це свідчить про необхідність імпортозаміщення ЛЗ за досліджуваною групою.

6. Аналіз середнього показника доступності кардіологічних препаратів показав незначне зниження, зокрема з 2,46 в 2016 р. до 2,33 в 2020 р., відповідно, що склало приблизно $5 \%$.

7. Узагальнені результати розрахунків ланцюгового індексу цін, показників адекватності платоспроможності та доступності у групі 4-го рівня ATXкласифрікації C01E X «Різні комбіновані кардіологічні препарати» показали, що зберігаються тенденції, характерні для усієї групи С01 «Кардіологічні препарати».

Конфрлікт інтересів: відсутній.

Conflicts of interest: authors have no conflict of interest to declare.

\title{
ANALYSIS OF SEPARATE GROUPS OF CARDIAC DRUGS' ECONOMICS AFFORDABILITY IN UKRAINE IN 2016-2020
}

\author{
N. A. Symonenko ${ }^{1}$, M. V. Podgaina ${ }^{2}$, A. S. Nemchenko², O. S. Shpychak ${ }^{1}$ \\ ${ }^{1}$ Institute for Advanced Training of Pharmacy Specialists (IATPS) of the National University of Pharmacy \\ ${ }^{2}$ National University of Pharmacy, Kharkiv \\ shpychak.oleg@gmail.com
}

The aim of the work. Analysis of the economic affordability of pharmacotherapeutic group of the II level of anatomical and therapeutic chemical classification - "Cardiac drugs" in the domestic pharmaceutical market in 2016-2020.

Materials and Methods. The data of distributors' offers were received on the Morion platform for 2016-2020, the offers of distributors by the group "Cardiac drugs", ATX code C01 were averaged. The analysis of retail prices for drugs of group C01 - cardiac drugs, and separately for group C01E X - Various combined cardiac drugs has been conducted. According to the results of calculations of the price chain index (IP), indicators of solvency adequacy (Cas) and economic affordability (D), general trends in the growth of retail prices of cardiac drugs in Ukraine over the past 5 years have been established and the need for import-substitution of drugs of the study group.

Results and Discussion. The highest value of the retail price index during 2016-2020 was characterized by group - C01 A - Cardiac glycosides, the lowest rate of price growth corresponded to group C01 B - Antiarrhythmic drugs. It was found

ISSN 2312-0967. Pharmaceutical review. 2021. № 2 
that all pharmacotherapeutic subgroups of group C01 were characterized by an annual decrease in the adequacy of solvency. At the same time, the dynamics of increasing economic affordability by an average of $5 \%$ was determined - from 2.46 in 2016 to 2.33 in 2020. It was found that for group C01E X "Different combined cardiac drugs" showed that the trends persist for the group C01 "Cardiological drugs".

Conclusions. The general tendency to moderate growth of prices has been determined, at the same time the calculated indicators of affordability allowed to determine the dynamics to the gradual growth of economic affordability of cardiac drugs, including group C01E X - Various combined cardiac drugs.

Key words: cardiovascular diseases; cardiac drugs; adequacy of solvency; affordability.

\title{
АНАЛИЗ ЭКОНОМИЧЕСКОЙ ДОСТУПНОСТИ ОТДЕЛЬНЫХ ГРУП КАРДИОЛОГИЧЕСКИХ ПРЕПАРАТОВ В УКРАИНЕ 3А 2016-2020 ГОДЫ
}

\author{
Н. А. Симоненко ${ }^{1}$, М. В. Подгайнаяㄹ, А. С. Немченко ${ }^{2}$, О. С. Шпичак ${ }^{1}$ \\ Институт повышения квалифрикации специалистов фрармации Национального фрармацевтического \\ университета, Харьков ${ }^{1}$ \\ Национальный фрармацевтический университет, Харьков ${ }^{2}$ \\ shpychak.oleg@gmail.com
}

Цель работы. Анализ экономической доступности кардиологических препаратов на отечественном фрармацевтическом рынке в 2016-2020 гг.

Материалы и методы. Данные по предложениям дистрибьюторов были получены на платорорме «Морион» за 2016-2020 годы, усреднено предложения дистрибьюторов по группе «Кардиологические препараты», код АТХ С01. Осуществлен анализ розничных цен за ЛС группы C01 - Кардиологические препараты и отдельно по группе C01E X - Различные кардиологические препараты. По результатам расчетов цепного индекса цен (Ip), показателей адекватности платежеспособности $\left(C_{a s}\right)$ и экономической доступности (D) установлены общие тенденции к росту розничных цен кардиологических препаратов в Украине в течение последних 5-ти лет, а также определена необходимость импортозамещения по ЛС исследуемой группы.

Результаты и обсуждение. Высоким значением индекса розничных цен в течение 2016-2020 годов характеризовалась группа - C01 A - Сердечные гликозиды, наименьший показатель роста цен отвечал группе C01 В - Антиаритмические средства. Установлено, что для всех срармакотерапевтических подгрупп группы С01 было характерно ежегодное снижение показателя адекватности платежеспособности. Одновременно определена динамика повышения экономической доступности в среднем на 5 \% по группе с 2,46 в 2016 г. по 2,33 в 2020 г. Установлено, что для группы C01E X «Различные кардиологические препараты» сохраняются тенденции, характерные для всей группы С01 «Кардиологические препараты».

Выводы. Определена общая тенденция к умеренному росту цен, вместе с тем рассчитаны показатели доступности позволили определить динамику к постепенному росту экономической доступности кардиологических препаратов, в том числе группы C01E X - Различные кардиологические препараты.

Ключевые слова: сердечно-сосудистые заболевания; кардиологические препараты; адекватность платежеспособности; экономическая доступность.

\section{Список бібліографічних посилань}

1. Про затвердження Державної стратегії реалізації державної політики забезпечення населення лікарськими засобами на період до 2025 року : постанова Кабінету Міністрів України від 5.12.2018 р. № 1022 (у ред. від 5.12.2018). URL: https://zakon. rada.gov.ua/laws/show/1022-2018-\%D0\%BF

2. World Health Organization. [Electronic resource, Geneva] Available from: www.who.int/cardiovascular diseases/ru/

3. Аналіз показників фрізичної доступності лікарських засобів у Харківському регіоні / Котвіцька А. А. [та ін.] // Соціальна фрармація: стан, проблеми та перспективи : матер. VI Міжнар. наук.-практ. інтернет-конореренції (23-24 квіт. 2020 р., м. Харків) / ред. кол. : А. А. Котвіцька та ін. - Харків : НФаУ, 2020. C. 16-27. URL: https://socpharm.nuph.edu.ua/wpcontent/blogs.dir/10/files/2020/05/socialna-farmaciya_ materiali-konferenciyi-2020.pdf

4. Гуз В. С., Заліська О. М., Максимович Н. М. Ретроспективний аналіз рецептів для лікування серцево-судинних захворювань упрограмі «Доступні ліки» на прикладі аптеки. Фармацевтичний журнал. 2020. Т. 75, № 3. - С. 69-79. DOI: 10.32352/0367-3057.3.20.07. URL: https://pharmj.org.ua/index.php/journal/article/view/884/829

ISSN 2312-0967. Фармацевтичний часопис. 2021. № 2 
5. Немченко А. С., Назаркіна В. М., Куриленко Ю. $€$. Оцінка стану фрармацевтичної допомоги хворим на серцево-судинні захворювання за результатами частотного аналізу призначень лікарських засобів. Соціальна фрармація в охороні здоров'я. 2018. Т. 4, № 3. C. 20-26. URL: https://dspace.nuph.edu.ua/bits tream/123456789/16579/1/141653-304991-1-PB.pdf

6. Доступні ліки. Міністерство охорони здоров'я. URL https://moz.gov.ua/dostupni-liki

7. Ретроспективний аналіз фрармацевтичного ринку кардіологічних препаратів в Україні за 2016-

\section{References}

1. On Approval of the State Strategy of State Policy Implementation of Providing the Population with Medicines for the period up to 2025: The Resolution of the Cabinet of Ministers of Ukraine of December, 5, 2018 No. 1022 (Ed. of December 5, 2018). Available from: https://zakon.rada.gov.ua/laws/show/1022-2018-\%D0\%BF.

2. World Health Organization. [Electronic resource, Geneva]. Available from: www.who.int/cardiovascular diseases/ru/

3. Kotvitska AA, Volkova AV, Kubarieva IV, Korzh YuV, Surikova IO. [Analysis of indicators of physical availability of medicines in the Kharkiv region]. Social Pharmacy: State, Problems and Prospects: Proceedings of the International Scientific and Practical Conference VI. April, 23-24, 2020. Khakriv: NFaU. Available from: https://socpharm.nuph.edu.ua/wp-content/blogs. dir/10/files/2020/05/socialna-farmaciya_materiali-konferenciyi-2020.pdf. Ukrainian.

4. Huz VS, Zaliska OM, Maksymovych NM. [Retrospective analysis of prescriptions for the treatment of cardiovascular diseases in the program "Affordable Medicines" on the example of a pharmacy]. Farmats zhurn. 2020;75(3): 69-79. DOI: 10.32352/0367-3057.3.20.07. Available from: https://pharmj.org.ua/index.php/jour-
2020 роки / Симоненко Н. А., Подгайна М. В. Немченко А. С., Шпичак О. С. Фармацевтичний журнал. 2021. Т. 77. № 3. С. 14-24.

8. Оцінка програми «Доступні ліки» В Україні. Європейське регіональне бюро Всесвітньої організації охорони здоров'я. Бюро ВООЗ в Україні. Originally issued in English by the WHO Regional office for Europe in 2019. - 60 c. URL: http://www.euro.who.int/ data/assets/ pdf file/0019/400429/52308-WHO-Affordable-Medicines-Programme-Ukraine-UKR_low_V7.pdf?ua=1

nal/article/view/884/829. Ukrainian.

5. Nemchenko AS, Nazarkina VM, Kurylenko YuYe. [Evaluation of the state of pharmaceutical care for patients with cardiovascular diseases based on the results of frequency analysis of drug prescriptions]. Sotsialna farmatsiia $v$ okhoroni zdorovia. 2018;4(3): 20-6. Available from: https://dspace.nuph.edu.ua/bits tream/123456789/16579/1/141653-304991-1-PB.pdf. Ukrainian.

6. Available drugs. The Ministry of Health of Ukraine. Available from: https://moz.gov.ua/dostupni-liki

7. Symonenko NA, Podhaina MV, Nemchenko AS, Shpychak OS. [Retrospective analysis of the pharmaceutical market of cardiac drugs in Ukraine for 2016-2020]. Farmats zhurn. 2021;77(3): 14-24. DOI: 10.32352/0367-3057.3.21.02. Ukrainian.

8. Evaluation of program "Available drugs" in Ukraine. European Regional Committee of the World Health Organization. Committee of WHO in Ukraine. Originally issued in English by the WHO Regional office for Europe in 2019. 60 s. Available from: http://www.euro.who. int/_data/assets/pdf_file/0019/400429/52308-WHOAffordable-Medicines-Programme-Ukraine-UKR_low_ V7.pdf?ua=1

\section{Відомості про авторів}

Симоненко Н. А. - аспірантка кафредри промислової фрармації та економіки, Інститут підвищення кваліфрікації спеціалістів фрармації, Національний фрармацевтичний університет МОЗ України, Харків, Україна. E-mail: nata2018@ gmail.com.

Подгайна М. В. - канд. фрармац. наук, доцент кафедри організації та економіки фрармації, Національний фрармацевтичний університет МО3 України, Харків, Україна. E-mail: sm211@ukr.net, ORCID: https://orcid.org/00000002-2088-0469.

Немченко А. С. - заслужений діяч науки і техніки України, д. фрармац. наук, професор, завідувачка кафредри організації та економіки фрармації Національного фармацевтичного університету МОЗ України, Харків, Україна. E-mail: asnemchenko@ukr.net, ORCID: https://orcid.org/0000-0003-1601-8881.

Шпичак О. С. - д. фрармац. наук, професор, завідувач кафедри промислової фрармації та економіки, Інститут підвищення кваліфрікації спеціалістів фрармації, Національний фрармацевтичний університет МОЗ України, Харків, Україна. E-mail: shpychak.oleg@gmail.com. ORCID: https://orcid.org/0000-0002-3015-8584.

\section{Information about the authors}

Symonenko N. A. - PhD-student of the Industrial Pharmacy and Economics Department, Institute for Advanced Training of Pharmacy Specialists, National University of Pharmacy of the Ministry of Health of Ukraine, Kharkiv, Ukraine. E-mail: nata2018@gmail.com, ORCID: https://orcid.org/0000-0002-3949-1826

ISSN 2312-0967. Pharmaceutical review. 2021. № 2 
Podgaina M. V. - PhD (Pharmacy), Associate Professor of the Organization and Economics of Pharmacy Department, National University of Pharmacy of the Ministry of Health of Ukraine, Kharkiv, Ukraine. E-mail: sm211@ukr.net, ORCID: https://orcid.org/0000-0002-2088-0469

Nemchenko A. S. - Honored Worker of Science and Technology of Ukraine, DSc (Pharmacy), Professor, Head of the Department of Organization and Economics of Pharmacy, National University of Pharmacy of the Ministry of Health of Ukraine, Kharkiv, Ukraine. E-mail: asnemchenko@ukr.net, ORCID: https://orcid.org/0000-0003-1601-8881

Shpychak O. S. - DSc (Pharmacy), Professor, Head of the Department of Industrial Pharmacy and Economics, Institute for Advanced Training of Pharmacy Specialists, National University of Pharmacy of the Ministry of Health of Ukraine, Kharkiv, Ukraine. E-mail: shpychak.oleg@gmail.com. ORCID: https://orcid.org/0000-0002-3015-8584 